\title{
Agrīnā otrās baltu valodas mācīšana: semantiskās paralēles
}

\section{Early second Baltic language teaching: semantic parallels}

\author{
Regīna Kvašìte \\ Šauḷu Universitāte, Sociālo, humanitāro zinātņu un mākslu fakultāte \\ Lietuviešu valodniecības, literatūras un komunikācijas katedra \\ P. Višinskio g. 38, Šiauliai LT-76352, Lietuva \\ E-pasts:kvasyte@hu.su.lt
}

Nepieciešamība lietuviešiem prast (mācīties) latviešu valodu un latviešiem - lietuviešu valodu ir plaši atzīta, īpaši bieži par to runā neoficiālā līmenī, taču realizēšana ierobežota dažādu iemeslu dēḷ. To îstenot varētu palīdzēt dažādi reǵionālo institūciju projekti, kuros paredzēta arī valodas mācīšana. Rakstā aplūkots pirmsskolas mācību iestāžu sadarbības projekts, kā arī šì projekta dalībnieku sagatavotā un izdotā mācību līdzekḷa materiāli. Pētījuma mērķis - analizēt lietuviešu un latviešu valodas leksiski semantiskās līdzības un atšksirības, kas jāņem vērā, mācot pirmsskolas vecuma bērniem otro baltu valodu Lietuvas un Latvijas pierobežā.

Pedagogu uzdevums ir pārdomāti izvēlēties valodas līdzekḷ̆us, lai š̀i vecuma bērnus nepārslogotu ar pārāk lielu izteiksmes dažādību, bet iemācītu sazināties radniecīgajā valodā. Viens no piemērotākajiem mācīšanas veidiem ir rotaḷnodarbības, kas rada bērnos motivāciju, rosina viņu radošumu. Konstatēts, ka agrīnā otrās baltu valodas mācīšana pierobežā var dot pozitīvus rezultātus, ja notiek kompleksi - gan iesaistot vecākus un vietējās kopienas, gan rīkojot apmaiņas braucienus, kopīgas nometnes u. tml.

Atslēgvārdi: latviešu valoda; lietuviešu valoda; agrīnā svešvalodas mācīšana; rotaḷnodarbības; leksiski semantiskā analīze.

\section{Ievads}

Latvijas-Lietuvas pārrobežu sadarbības programmas projektu LatvijasLietuvas pierobežas reǵiona pirmsskolas mācību iestāžu sadarbības sistēmas radīšana (liet. Latvijos-Lietuvos pasienio regiono ikimokyklinio ugdymo istaigu bendradarbiavimo sistemu sukūrimas) 2010.-2011. g. 1̄stenoja divi pierobežas 
bērnudārzi - Pakrojas rajona Žeimeles (liet. Žeimelis) ${ }^{1}$ bērnudārzs Ąžuoliukas un Bauskas rajona Rundāles novada bērnudārzs Mārpuķìte $e^{2}$. Viens no daudzajiem projektā paredzētajiem uzdevumiem bija saistīts ar pirmsskolas vecuma bērnu izglītošanu, resp. otrās baltu valodas mācīšanu. Runājot par pierobežu, kur daudzi iedzīvotāji kaut minimāli prot kaimiņvalsts valodu, precīzāk būtu lietot terminu otrā valoda, taču definīcijas latviešu valodas nozaru terminu vārdnīcās to darīt neḷauj, jo tā tiek saukta ,,[k]ādas valsts sabiedrības vairākuma (majoritātes) valoda, ko lieto kā sazināšanās līdzekli (valsts valodu) attiecīgajā valstī un ko mācās, apgūst un lieto minoritātes pārstāvis, kuram tā nav dzimtā valoda. Ne vienmēr tā ir otrā valoda apguves secīguma ziņā” (Skujiņa et al. $2000,115)$ vai ,[k]ādā valstī oficiāli lietota valoda (valsts valoda) vai majoritātes valoda, ko apgūst un lieto minoritātes pārstāvji, kuriem tā nav dzimtā valoda; valoda, kuru secīgi apgūst pēc pirmās (dzimtās) valodas” (Skujiņa et al. 2011, 59). Oficiāli latviešu un lietuviešu valoda viena attiecībā pret otru ir svešvaloda, tomēr termins svešvaloda pētījuma ietvaros nav piemērots, jo attiecināms uz citām svešvalodām, piem., angḷu, krievu, vācu, kuras pierobežas bērniem arī var tikt mācìtas agrīnajā vecumā (sal. „otrās valodas situāciju nevar salīdzināt ar svešvalodas apguves situāciju” (Šalme 2011, 24-25)). Rakstā galvenokārt lietots termins otrā baltu valoda, kas raksturo situāciju no abu valodu pozīcijām. Šādu terminu izvēli daḷēji balsta lietuviešu lingvodidaktikas terminolog̣ijā pieņemtais skatījums uz otro valodu (sal. antroji kalba ,asmens kalba,

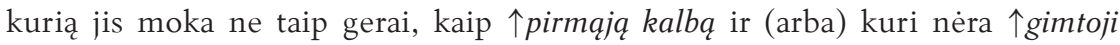
kalba [..]" [personas valoda, kuru viņš prot ne tik labi kā pirmo valodu un (vai) kura nav dzimtā valoda]) (Ramonienè et al. 2012, 22-23).

Pētījuma mērķis - analizēt lietuviešu un latviešu valodas leksiski semantiskās līdzības un atškirinibas, kas jāņem vērā, mācot pirmsskolas vecuma bērniem otro baltu valodu Lietuvas un Latvijas pierobežā. Avoti - Žeimeles un Rundāles pirmsskolas mācību iestāžu sadarbības projektā sagatavotā un izdotā mācību līdzekḷa materiāli, kā arī citi valodu mācīšanas materiāli, un šì projekta

Mazpilsētas nosaukums mūsdienu lietuviešu valodā ir Žeimelis, bet latvieši to tradicionāli mēdz saukt par Žeimi, kaut gan tuvāks lietuviskajam oriǵinālam būtu atveidojums Žeimele. Kā apgalvo lietuviešu onomastikas pētnieks Aleksandrs Vanags (Aleksandras Vanagas), ,,[M]ūsdienu mazpilsētas vārda forma Žeimelis, šksiet, ir nedaudz vēlāka, sekundāra. Pēc A. Saḷa datiem, vietējie cilvēki lietojuši tikai Žeimys [..]. Pēc kara pilnībā nostiprinās Žeimelis - 1948. g. to rekomendēja „Lietuviešu valodas pareizrakstības vārdnīca” (forma Žeimys tajā dota iekavās), citi normatīvie izdevumi [..]. İsais vārda variants pirmoreiz pierakstīts 1500. g." (Vanagas 1996, 300-301). Tādas vietvārda pārmaiņas cēlonis varēja būt latviešu valodas „,sugasvārdi (Žeimele ir Latvijas pierobežā) ziemeḷi, ziemelis. Turklāt izskaņa -el- Zemgales vietvārdiem vispār raksturīga" (Vanagas 1996, 301).

2 Par šo projektu informācija ir atrodama gan Pakrojas pašvaldības mājaslapā (http://www.pakruojis.lt/lit/Pakruojyje-aptarti-Latvijos-ir-Lietuvos-bendradarbiavimo-klausimai-/3297; http:// www.pakruojis.lt/lit/Zeimelio-darzeliui--Latvijos-parlamentaru-dovanos-ir-padeka-/3397), gan atsevišşāās publikācijās citās interneta vietnēs un presē (Koskienẻ 2012), arī konferenču materiālos (Kvashite 2011). 
īstenošanas gaitā gūtā pieredze. Pētījums veikts, izmantojot sastatāmo un aprakstošo metodi.

\section{Agrīnā baltu valodas mācīšana}

Atšķirīgi viedokḷi par agrīno valodas mācīšanu - tās derīgumu vai, tieši otrādi, kaitīgumu - ir pārstāvēti gan Latvijā, gan Lietuvā (Dabašinskienè, Garuckaite 2009), taču, piekrītot domai, ka dzimtā valoda (valodas didaktikā saukta par pirmo valodu ${ }^{3}$ ), ,pamatos tiek apgūta $\bar{l}_{\mathrm{d}} \mathrm{k}$ četru gadu vecumam, tās apguve turpinās visu mūžu” (Druviete 2000), nav šaubu, ka paralēli var tikt izmantota vai arī speciāli mācīta cita valoda. „Otru (trešo, ceturto utt.) valodu [..] papildus varam sākt mācīt jebkurā bērna vai pieaugušā dzīves posmā. Pašlaik atzīts, ka nav tāda kritiskā perioda (piem., otrais dzīves gads, skolas gaitu sākums, rakstītprasmes apguve), kad nebūtu vēlama citu valodu mācīšana. Turklāt ir apstiprinājies uzskats par agrīna vecuma priekšrocībām valodas apguvē. Smadzeņu metaboliskā aktivitāte visaugstākā ir 2-12 gadu vecumā, kad aktivitāti vēl nav zaudējušas arī valodas apguvi kontrolējošās sinapses. Tātad pašreizējā nostādne ir: līdz 10-12 gadu vecumam, cik vien iespējams, jāattīsta gan dzimtās valodas, gan citu valodu prasme” (Druviete 2000).

Sadarbības projektā tika sarīkots seminārs Žeimelē abu partneriestāžu darbiniekiem Agrīnā svešvalodu mācīšana bērnudārzā, kura mērķis - sagatavot abu Lietuvas un Latvijas pierobežas bērnudārzu audzinātājus (pedagogus), lai sāktu otrās baltu valodas agrīnās mācīšanas programmu. Šajā kontekstā vispirms svarīgi ir novērtēt citu svešvalodu, galvenokārt krievu un angḷu, lomu mūsdienu Latvijas un Lietuvas valodas situācijā. Nav šaubu, ka vairums minēto bērnudārzu darbinieku prot krievu valodu, jo viņu vidējais vecums ir ap 40 gadiem (ka abu valstu jaunā paaudze krievu valodu prot vāji vai neprot nemaz, liecina dažādi novērojumi un pētījumi) un neformālā savstarpējā pieaugušo saziņa var notikt (un notiek) krievu valodā. Tāpēc viens no semināra, kā arī projekta kopumā, mērķiem - sagatavot pedagogus mācīt bērniem otro baltu valodu cieši saistīts ar viņu pašu motivēšanu neizmantot trešo saziņas valodu (jaunā paaudze krievu valodas vietā acīmredzot izvēlētos angḷu valodu). Žeimeles un Rundāles bērnudārzu pedagogi piedalījās metodiski praktiskajā seminārā, kura gaitā izkristalizējās nostādne, ka racionāli būtu pēc iespējas plašāk iesaistīt mācību procesā otrās valsts speciālistus (audzinātājus un pedagogus), kuri mācītu bērniem savu dzimto valodu. Taču arī pašu valsts pedagogiem aktīvi jāpiedalās šajā darbā.

Žeimeles bērnudārza audzinātājas lietuviešu un latviešu valodas mācīšanai sagatavoja un izdeva divvalodu mācību līdzekli Pažink save ir savo

\footnotetext{
3 Plašāk dažādais terminu traktējums šajā rakstā netiks aplūkots.
} 
draugus. Iepazīsti sevi un savus draugus un tā pielikumu (Krūminienè, Motviekaitė 2010a un 2010b; sk. 1. att.), kuru var izmantot dažādas pierobežas mācību iestādes (gan bērnudārzi, gan skolas). Uzdevumu grāmatiņā aprakstītas komunikācijas situācijas, formulēti uzdevumi, kuru mērķis - iemācìt konkrētai situācijai nepieciešamos vārdus (šie vārdi vēlreiz uzsvērti sadạ̦ā Iegaumēe), kā arī sniegti tematiski abilstošu muzikālo un kustību rotaḷu, spẹ̄̂u apraksti . Darbā ar bērniem pedagogiem varētu noderēt arī projekta Lietuviešu un latviešu stundu cikls pierobežas reǵionos (liet. Lietuvių ir latvių kalbu pamokų ciklas pasienio regionuose $)^{5}$ ietvaros izdotie palīglīdzekḷi Baltu kalbu pradžiamokslis. Baltu valodu ābece (Vaisvalavičienè; Butkienè, Vaisvalavičienè), kā arī citi avoti, kas paredzēti lietuviešu un/vai latviešu valodas apguvei, piem., vārdnīcas ${ }^{6}$ (Balkevičs et al. 1995; Butkienè 1998; Butkus 2003).
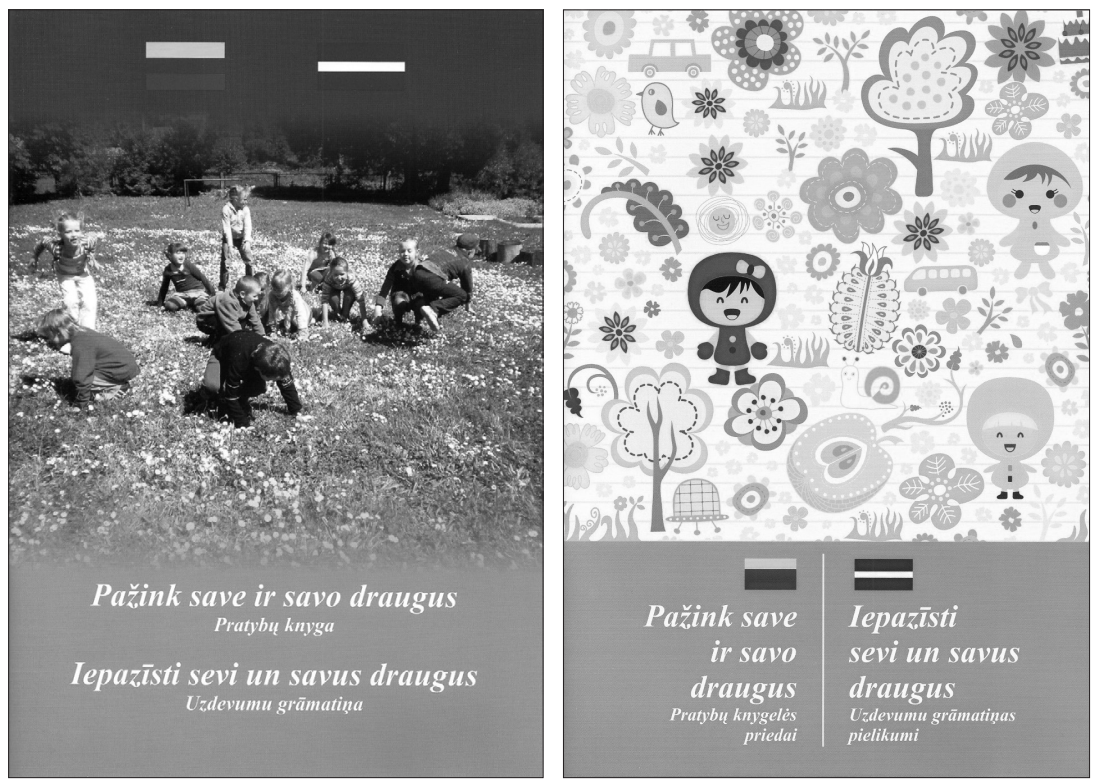

1. attēls. Projektā izdotie mācību līizekḷi (Krūminienè, Motviekaitė 2010a un 2010b).

4 Mācību līdzekḷi adresēti pedagogiem, tāpēc uzdevumu u. c. apraksti paredzēti pieaugušajiem, tikai reizēm iejūtoties bērna lomā.

5 Šādu projektu ar Lietuvas Republikas Ārlietu ministrijas atbalstu pierobežas skolās vairākos posmos îstenoja Vītauta Dižā Universitātes (Kauņa) Letonikas centrs (plašāk par šo projektu sk. Lietuvas Ārlietu ministrijas darbības pārskatu (https://www.urm.lt/default/lt/2006m-veiklos-ataskaita), Lietuvas un Latvijas foruma asociācijas informāciju (http://www.lt-lv-forum. org/19014/iniciat\%C4\%ABvas.html?arx=1), arī http://www.delfi.lt/news/daily/education/ baltu-kalbu-pamokos-lietuvos-ir-latvijos-pasienyje.d?id=10702637 u. c.).

6 Abu virzienu divvalodu vārdnīcas ir pieejamas arī www.letonika.lv 


\section{Valodas materiāla analīze}

Mācot kaimiņvalsts resp. otro baltu valodu, jāṇem vērā vēsturiski izveidojusies valodu radniecība. Tieši latviešu un lietuviešu valodu tuvums izvirza prasību rūpīgi izvēlēties valodas materiālu. Šì prasība ir spēkā gan pedagogiem, kuri mācīs pirmsskolas vecuma (ne vien projektā iesaistītos) bērnus, gan tiem cilvēkiem, kuri jebkurā vecumā kā svešvalodu apgūs lietuviešu vai latviešu valodu. Mācību līdzeklī̄ paredzēts, ka sevis un apkārtējās vides iepazīšana notiek vienlaikus abās valodās - bērns mācās nosaukt sevi, savus g̣imenes locekḷus, kā arī apkārt esošus priekšmetus u. tml. dzimtajā valodā un otrajā baltu valodā. Pedagogiem, kuri strādā ar bērniem, jāņem vērā semantiskās atsevišş latviešu un lietuviešu valodas vārdu atšķirības, jādomā arī par teikumu uzbūvi vai sintaktisko konstrukciju izvēli, lai izteiktu dažādas attieksmes u. tml.

\subsection{Semantikas atšķirības}

Leksikā svarīgi ir izprast dažādu vārdšķiru vārdu semantiku un tās atšķirības $^{8}$. Daļa semantiski neatbilstošu vārdu atrodami arī pētījuma avotā, jo nereti tie ir jāapgūst jau mācību sākumposmā (iekavās norādītas attiecīgās mācību līdzekḷa lappuses). Piem., gan mācot valodu, gan sazinoties tajā, īpaša uzmanība jāpievēerš atsevišķ ki lietvārdu semantikas atškịirībām:

(1) latv. spalva - liet. plunksna, bet liet. spalva (izrunājot uzsvērta ir pēdējā zilbe) nozīmē 'krāsa' (sal. uzdevuma noteikumos lietotās darbības vārdu formas nuspalvink - izkrāso $(38 ; 46)$

(2) latv. nauda - liet. pinigai, bet liet. nauda (izrunājot uzsvērta ir pēdējā zilbe) nozīmē 'labums' (šis vārds ir aktuāls, iepazīstoties ar ikdienā svarīgām abu valstu reālijām, tostarp naudas vienībām $\left.{ }^{9}\right)(39)$

(3) latv. skola - liet. mokykla, bet liet. skola (jānnem vērā izrunas ìpatnības: burta o izruna latviešu valodā un lietuviešu valodas uzsvars - šajā gadịjumā uzsvērta ir pēdējā zilbe) nozīmē 'parāds'

7 Par piemēru avotu izmantots galvenokārt šis mācību līdzeklis (tā pielikumā ir tikai zīmējumi), tāpēc, atsaucoties uz šo avotu, rakstā iekavās tiks lietoti tikai lappušu numuri (pie tiem piemēriem, kuri ir iekḷauti šajā mācību līdzeklī). Raksta mērķis nav vērtēt mācību līdzekḷa kvalitāti, jo tas ir pirmais tāda veida divvalodu izdevums, kura autores - bērnudārza audzinātājas. N̦emot par pamatu materiāla tematiku, uzmanība pievērsta galvenokārt latviešu un lietuviešu valodas leksiski semantiskajām paralēlēm.

8 Neliels pēc formas līdzīgu, bet pēc nozīmes atšķirīgu lietuviešu un latviešu vārdu kopums ir iekḷauts Alvīda Butkus (Alvydas Butkus) grāmatās Mūsų broliai latviai (1990) un Latviai (1995).

9 Laikā, kad uzdevumu grāmatiņa izdota, Latvijā nacionālā valūta bija lats, bet Lietuvā - lits. Pašreiz būtu jāpievērš uzmanība naudas vienības nosaukuma formu atšķirīibām: latv. eiro - liet. euras. 
(4) liet. debesis - latv. mākonis (sal. latv. lietvārda debess daudzskaița forma debesis; jāṇem vērā, ka atškiras ne tikai nozīme, bet arī lietvārdu gramatiskā dzimte)

(5) latv. veikals - liet. parduotuve, bet liet. veikalas (atšķiras tikai galotne, taču tā ir raksturīga abu valodu vīriešu dzimtes lietvārdiem, turklāt atsevišķām lietuviešu valodas izloksnēm ir raksturīga galotņu īsināšana, tāpēc tieši Latvijas un Lietuvas pierobežas iedzīvotāju runā tā var nebūt būtiska pazīme) nozīmē 'darbs, sacerējums, gara ražojums, gara produkts' (Balkevičs et al. 1995, 569) (40)

(6) latv. burts - liet. raide, bet liet. burtas (atšksiras tikai galotne, taču tā ir raksturīga abu valodu vīriešu dzimtes lietvārdu atšksirība, turklāt atsevišķām lietuviešu valodas izloksnēm ir raksturīga galotņu īsināšana, tāpēc tieši Latvijas un Lietuvas pierobežas iedzīvotāju runā tā var nebūt būtiska pazīme) nozīmē '1. loze; 2. burvība' (Balkevičs et al. 1995, 85)

(7) latv. tārps - liet. kirmèle, kirminas (Butkus 2003, 715), bet liet. tarpas (vārda izruna ir l̦oti tuva, atšķiras tikai ar lietuviešu valodas vīriešu dzimtes lietvārdiem raksturīgo galotni) nozīmē 'starpa' (Balkevičs et al. 1995, 520) (14)

(8) latv. pell,e - liet. bala, klanas (Butkus 2003, 541), bet liet. pelké (izruna nedaudz atšķiras, taču ne tik l̦ oti, lai, mācoties valodu, nevarētu šo vārdu nozìmes sajaukt) nozīmē 'purvs' (Balkevičs et al. 1995, 364)

Semantiskas atšķirības pastāv arī starp latviešu un lietuviešu valodas īpašības vārdiem (plašāk par š̄s vārdškiras semantikas atbilsmēm sk. Trumpa 2010). Daži no tiem pieder pie pamatleksikas resp. ir aktuāli ikdienas saziņā, tāpēc ir jāapgūst jau valodas apguves sākumposmā, piem.:

(9) latv. jauns - liet. jaunas (atšķiras tikai abu valodu īpašības vārdu galotnes) nozīmē tikai '1. [t]āds, kam ir samērā neliels vecums [...' (Ceplītis, Stengrevica 4, 198), savukārt citas šì latviešu vārda nozīmes izsaka lietuviešu naujas, šviežias (par kartupẹ̦iem) (Butkus 2003, 308)

(10) latv. skaists - liet. gražus (Butkus 2003, 668), bet liet. skaistus atkarībā no konteksta var tulkot '1. košs, spilgts, skaidrs, gaišs; 2. godīgs, nevainīgs' (Balkevičs et al. 1995, 446)

(11) latv. jautrs - liet. linksmas, smagus, gyvas (Butkus 2003, 309) (sal. 'līksms, jautrs, priecīgs, dzīvespriecīgs' (Balkevičs et al. 1995, 268), bet liet. jautrus atkarībā no konteksta var tulkot l̦oti dažādi: '1. jutīgs, jūtīgs, jūtelīgs; 2. modrs, vērīgs, smalkjūtīgs, atsaucīgs' 
(Balkevičs et al. 1995, 268) (sal. uzdevumu nosaukumu Linksmoji sauluté/Lautrā saulīte $\left.(25)^{10}\right)$

Latviešu un lietuviešu valodā sastopami ar semantiski atškirīgi darbības vārdi, kuru mācīšanai jāpievērš ìpaša uzmanība, turklāt pedagogiem ir jābūt gataviem, ka nereti to nozīmju atšķirības varētu izraisīt jautrību, īpaši bērniem), piem.:

(12) latv. dejot - liet. šokti, bet liet. dejuoti (divskanis uo lietuviešu valodā tiek attiecīgi pierakstīts, savukārt darbības vārdu nenoteiksmes rādītājs ir $-t i$ ) atkarībā no konteksta tulko 'vaimanāt, vaidēt, stenēt, kunkstēt, gausties, žēloties' (Balkevičs et al. 1995, 96) (ne mazāk dīvains lietuviešiem šķiet arī š̄s saknes latviešu valodas lietvārds, jo tas sakrīt ar izsauksmes vārdu deja 'diemžēl' (izrunā, uzsverot pēdējo zilbi)

(13) latv. atbildēt - liet. atsakyti, bet liet. atbildèti nozīmē 'atnākt (atbraukt) ar troksni (rīboņu), atrībināt' (Balkevičs et al. 1995, 52)

(14) latv. braukt - liet. važiuoti, bet liet. braukti nozīmē '1. svītrot; 2. braucìt (lapas, ogas), slaucìt (asaras, sviedrus); 3. sukāt (linus no pogal̦ām); 4. kulstìt (atspalıtot linus); 1. sar. ātri steigties' (Balkevičs et al. 1995, 82) (varētu pieminēt arī līdzīgu, kaut gan neaktuālu pirmsskolas vecuma bērniem latviešu valodas darbības vārdu važot '[s]aistìt ar važu' (Ceplītis, Stengrevica 1996, 331))

Īpaša uzmanība jāpievērš daudznozīmīgiem lietvārdiem un darbības vārdiem, lai nošķirtu to nozīmju atbilsmes otrā baltu valodā un vispirms iemācītu bērniem vajadzīgāko (piemērotāko) vai semantiski runas kontekstam atbilstošāko, piem.:

(15) latv. vārds - liet. vardas kā personas vārds un žodis kā „valodas pamatvienība .." (Skujiņa et al. 2007, 436) (14; 21; 22; 42)

(16) liet. žaidimas - latv. spēle un rotaḷa (sal. darbības vārdus spēlēties un rotaḷaties, arī rotaļnodarbība) $(16 ; 22 ; 33 ; 38 ; 45)$

(17) latv. spēlèt - liet. groti (smuiku) 'spēlēt vijoli' un žaisti (krepšinį) 'spēlēt basketbolu' (sal. arī spèlēties)

(18) latv. lasìt - liet. skaityti (knygą) 'lasìt grāmatu' un rinkti (uogas) 'lasìt ogas' (sal. latv. skaitīt - liet. skaičiuoti)

Daži iepriekš aplūkotie piemēri liecina: ja pieaugušais sāk mācīties valodu, viņam ir vēlēšanās un iespēja salīdzināt abu valodu formas, savukārt, mācot pirmsskolas vecuma bērnus, līdzības un atškirīibas ir jā(pa)redz pedagogam.

${ }^{10}$ Mācību līdzeklī latviešu valodā konsekventi visos gadījumos lietots viens un tas pats īpašības vārds, piem., iegaumēšanai paredzēto vārdu sarakstā arī ir linksmas - jautrs (44). 


\subsection{Sinonīmu un deminutīvu izvēle}

Lai atvieglotu valodas apguvi, īpaši svarīga ir piemērotāko vārdu izvēle. Mācību sākumposmā ieteicams izvēlēties pirmsskolas vecuma bērnam vieglāk iegaumējamu vārdu cilvēka, sadzīves priekšmeta, vides objekta u. tml. nosaukšanai, ja svešvalodā lieto vairākus sinonīmus. Tas varētu būt vienkāršăkais, plašāk lietotais, stilistiski neitrālākais, vieglāk izrunājamais vai universālākais izvēles kritēriju daudz, tie var būt subjektīvi, atkarīgi no runas situācijas. Piem., vienu un to pašu sadzīves priekšmetu, ko latviešu valodā sauc par grozu vai groziņu, lietuviešu valodā var saukt gan krepšys un krepšelis, gan pintine pintinèlè. Pirmā atbilsme sastopama mācību līdzeklī (22), otrās šajā izdevumā nav, taču kādā citā avotā tā var būt, jo ir lietuviešu valodā; vārdus taurenis (tauriņš), taurenìtis lietuviski var tulkot gan drugys, drugelis (14), gan plaštaké u. tml. Neraugoties uz to, ka ne visi leksiskie sinonīmi mācību līdzeklī atspoguloti, pedagogiem labi jāpārzina leksikas dažādība, lai nepārslogotu bērnus ar nevajadzīgu informāciju. Piem., lietuviešu valodas vārdam berniukas kā stilistiski neitrālākā atbilsme izvēlēts vārds zèns, kaut gan latviešu sarunvalodā plaši lieto vārdus puika, arī puisītis, puisēns u. tml. Šie vārdi ir iekḷauti arī latviešu valodas sinonīmu vārdnīcā (Rauhvargers 2002, 464-465). Domājams, ka šis ikdienas saziņā plaši izplatītais vārds būtu jāiemāca, lai komunikācija ārpus nodarbībām būtu veiksmīga. Daži aplūkotie leksēmu (ne)atbilstības gadījumi rāda, ka pedagogiem gan analizējamais, gan citi mācību līdzekḷi jāizmanto radoši un kritiski, jo arī tajos ne vienmēr izdevies izvairīties no pārmērīgas izteiksmes dažādības.

Citu aktuālu otrās baltu valodas mācǐšanas jautājumu ilustrē vēl viens piemērs no pētījuma avota. Bērniem piedāvāts iemācīties skaitāmpantu, kurā lietuviešu un latviešu tekstā lietoti atškirīgi darināti sinonīmi [tālāk retinājums mans - R. K.]:

(19) Viens ${ }^{11}, d u$, trys / Višta ir gaidys, / Aš vište elè, / Tu ga id ži u k a s, / Viens, du, trys //

Viens, divi, trīs / Vista un gailis, / Es vi s ti ņa, / Tuga i lì tis, / Viens, divi, trīs (27).

Latviešu valodas vārdiem gailis, gailītis lietuviešu valodā atbilst vārdi gaidys, gaidžiukas (27), gaidelis (29), savukārt vista, vistinga - višta (29; 31), vištytè (31), vištelè (27). Tieši deminutīvus ar piedēkli -el- lietuviešu valodā lieto biežāk. Salīdzinājumam var minēt bērnu dziesmiņu Du gaideliai, kurā ir

${ }^{11}$ Lietuviešu valodas forma ir vienas, taču skaitāmpantā ērtāka šķitusi forma ar reducētu galotni; tādas raksturīgas arī Ziemeḷlietuvā runātajām izloksnēm. 
tie paši deminutīvi (šo dziesmu latviski ir atdzejojis Ziedonis Purvs un nosaucis Divi gaili i):

(20) Du gaid elia i, du gaid elia i baltus žirnius kūlè,

Dvi viš te lè s, dvi viš te lès $\dot{i}$ malūnq vežé. //

Divi gaili, divi gaili baltus zirņus kūla,

Divas vistas, divas vistas zirnus mājās veda (45)

(sal. burtiski Div’ gailǐši, div' gailī̌si baltus zirṇus kūla / Div’ vistinas, div' vistinas uz dzirnavām veda).

Nav šaubu, ka reizēm valodisko izteiksmi ietekmē dzejoḷa (dziesmas, rotal̦as) teksta ritms ${ }^{12}$, taču arī citos gadījumos nākas izvēlēties piemērotāko ekvivalentu no vienas vai otras valodas vārdu virknes. Parasti izvēle notiek starp diviem ekvivalentiem, no kuriem viens ir neitrāls vārds, otrs var būt stilistiski iekrāsots, bieži vien deminutīvs. Taču šajā piemērā redzams, ka latviskajā dzejoḷa versijā nav saglabāts neviens deminutīvs.

Tā kā gan lietuviešu, gan latviešu valodai piemīt lielas deminutīvu darināšanas potences, tie bieži sastopami bērniem adresētos tekstos. „Deminutīvformu lietojums ir izplatīts arī pirmsskolas pedagogu runā un ir viens no pozitīvās saskarsmes nosacījumiem, tomēr ir ieteicams pedagog̣iskajā procesā lietot abas vārdu formas, bagātinot bērna vārdformu krājumu, kā arī nepārspīlējot pamazinājuma izteiksmi mazā bērna pasaulainā [..]” (Markus, Zīinna 2016, 205). Par to, ka „deminutīvs ir nozīmīgs bērna emocionālās pieredzes veidošanas komponents" (Vulāne 2007, 80), iespējams pārliecināties, analizējot projekta materiālus. „Ikdienā lielākoties tiek izmantoti personvārda, radniecības terminu deminutīvi, piem., Liene, Lienīte, Lieņuks, Lieņucìtis, Valdiñ̌̌, Vilītis, meitina, meitucītis, meituks, dèliņš, dèluks, dèlucìtis, māmiņa, mammucis, tētuks, omīte, opītis, brālītis, brāluks, māsinga, māšuks, māšele u. tml. [..]” (Vulāne 2007, 82). Līdzīga pamazinājuma un/vai mīlinājuma atvasinājumu dažādība raksturīga arī lietuviešu valodai (plašāk sk. Macienè 2002; 2005). Latviešu valodai raksturīgo radniecības terminu māte un têvs deminutīvu dažādību ir analizējusi Velta Rūķe-Draviņa, uzsverot arī līdzību ar lietuviešu valodas iespējām (Rūķe-Draviņa 2017, 70). „Deminutīvs izsaka arī tuvākas, maiguma pilnas attiecības, kas bieži vien izpaužas vārdu tēvs/māte, brālis, māsa lietojumā, kur deminutīvs var būt izmantots gan ritma labad [runa ir par latviešu tautasdziesmām, taču teiktais var tikt attiecināts arī uz citiem tekstiem R. K.], gan ar nolūku akcentēt tuvinieku nozīmīgumu cilvēka dzīiē [..]” (Vulāne 2007, 88).

12 Līdzīgi kā tautasdziesmās, arī citētā dzejoḷa burtiskajā atdzejojumā labāk iederas bezgalotnes forma div'. 
Raugoties no dzimtās valodas viedokḷa, potenciāli lietojamo vārdu, tostarp arī deminutīvu, ir daudz vairāk, tāpēc pedagogam, izmantojot mācību līdzekḷus vai runājot, jācenšas nepārspīlēt, izvēloties apgūstamās valodas vārdus. Salīdzinājumam gribētos pieminēt dažus abu valodu sinonīmu vārdnīcu datus, neiedzį̣inoties nozīmju vai lietojuma niansēs: latviešu valodas sinonīmu vārdnīcā fiksēti 20 vārda māte sinonīmi (Rauhvargers 2002, 217), lietuviešu valodā - 18 vārda motina sinonīmi (Lyberis 2002, 264), latviešu valodā 9 vārda tềrs sinonīmi (Rauhvargers 2002, 425), lietuviešu valodā 10 vārda tèvas sinonīmi (Lyberis 2002, 422) u. tml. Jādomā, ka, mācot otro baltu valodu, sākumā pilnīgi pietiktu ar dažām leksēmām (svarīgi būtu tās konsekventi atkārtot) katrā no valodām, lai nosauktu tuvākos gímenes locekḷus u. c. personas, priekšmetus, parādības. Turklāt ieteicams veidot vienotu sistēmu, piem., ğimenes locekḷu nosaukšanai izmantot vārdus māte, mamma, māmiņa - motina, mama, mamytè, tềvs, têtis - tèvas, tètis, meita, meitina-dukra, dukrelè, dukryté, dēls, dèlin,š - sūnus, sūnelis u. tml.

\section{Personvārdu salīdzinājums}

Pirmsskolas vecumā aktuāls varētu būt personvārdu ${ }^{13}$ salīdzinājums, jo iepazīstoties bērni vispirms uzzina cits cita vārdu. Arī par pētījuma avotu izvēlētais mācību līdzeklis sākas ar iepazǐšanos. Satiekas meitene un zēns, kurus sauc tāpat kā bērnudārzu, kuru katrs no viņiem pārstāv:

(21) Mano vardas Mar pukytè ir aš gyvenu Latvijoje. / Mans vārds

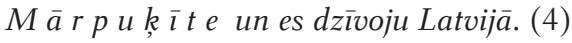

(22) Aš esu Ąžu oliukas. Gyvenu Lietuvoje. / Es esmu Āžoḷuks. Dzīvoju Lietuvā. (4)

Uzdevumu grāmatināa pārdomāti un radoši sniegtā informācija var radīt grūtības, ja otrās valodas lietotājam jāpaskaidro nosaukumu nozīme. Ąžuoliukas, kas varētu būt reālas personas vārda deminutīvs (Ą̌zuolas ir pasakas Egle žalkšu karaliene (liet. Eglè žalčiu karalienè) varones Egles vecākā dēla vārds; lietuviešiem ozols ir stipruma simbols (Kuzavinis, Savukynas 1994, 88), latviskojams kā Āžoḷuks (sal. Ąžuolas - $\bar{A} z ̌ o l s)$, kaut gan kā sugasvārda (domājams, ka tieši tas ir nosaukuma pamatā) nozīme ir ozoliņ̌š. Savukārt Mārpuķìte ir puķe, ko lietuvieši sauc saulutè resp. saulīte, nosaukums. Taču mācību līdzeklī personas identificē latviskoti/lietuviskoti avotvalodas vārdi.

Interesi bērniem var izraisīt Lietuvā un Latvijā iegūto draugu un draudzeņu vārdi. Lai izvairītos no nepatīkamas situācijas vai pat izsmiekla,

${ }^{13}$ Sal. priekšvārds ' [c]ilvēka vārds, ko jaundzimušajam dod pēc dzimšanas un ko ieraksta dzimšanas pamatdokumentā ..' (Skujiņa et. al. 2007, 311). 
audzinātājiem (pedagogiem) jau iepriekš jāparedz, ka daži no tiem var būt neparasti. Piem., latviešu zēna vārds Ģirts pēc savas formas ir tuvs lietuviešu valodas īpašības vārdam girtas 'piedzēries' (tieši tā šis vārds gramatiski pareizi atveidojams lietuviski), bet lietuvieša vārds Aidas (latviskotais veidols Aids), savukārt vārda Kastytis latviskotais veidols Kastītis asociējas ar sieviešu dzimtes deminutīvu kastīte resp. maza kaste. Dažos gadījumos ir iespēja izvēlēties neitrālākas formas ar galotni -is - Girtis, Aidis (plašāk par lietuviešu un latviešu personvārdu atveidi otrā baltu valodā sk. Kvašīte 2011). Ne viens vien meiteņu un zēnu vārds iekḷauts uzdevumu grāmatiņā: piedāvāts tos sagrupēt resp. „salikt groziņos” (sal. „Groziņā, pie kura ir Āžoḷuka cepurīte, ar bultām savelc lietuviešu vārdus, bet groziņā, pie kura zied pukīite, ar bultām savelc latviešu vārdus ..”; sk. 2. att.) pēc piederības latviešiem vai lietuviešiem.

\begin{tabular}{|c|c|c|c|c|}
\hline $\begin{array}{l}\text { LAIMA } \\
\text { ELITA } \\
\text { AUDRA } \\
\text { AGITA } \\
\text { SANTA } \\
\text { EGIDIJUS } \\
\text { RASA } \\
\text { GUNDARS } \\
\text { KITIJA } \\
\text { SARMĪTE } \\
\text { INGA } \\
\text { PATRICIJA } \\
\text { VIVITA } \\
\text { ALVITA } \\
\text { DACE }\end{array}$ & $\begin{array}{l}\text { RALFS } \\
\text { GUNTA } \\
\text { VILMA } \\
\text { LAURA } \\
\text { MĀRIS } \\
\text { KATRĪNA } \\
\text { BEATA } \\
\text { JUSTAS }\end{array}$ & $\begin{array}{l}\text { BENEDIKTAS } \\
\text { ERIKAS } \\
\text { LIUDAS } \\
\text { LINA } \\
\text { REGINA } \\
\text { UGNE் } \\
\text { IRMA } \\
\text { MATAS }\end{array}$ & $\begin{array}{l}\text { AGNĖ } \\
\text { ANGELE் } \\
\text { KRISTINA } \\
\text { ALEKSANDRA } \\
\text { ODETA } \\
\text { JĀNIS } \\
\text { JONAS } \\
\text { REGĪNA }\end{array}$ & $\begin{array}{r}\text { LAURIS } \\
\text { KAROLINA } \\
\text { ROKAS } \\
\text { DAIVA } \\
\text { DIANA } \\
\text { RENATAS } \\
\text { MARKUSS } \\
\text { LITA } \\
\text { ULDIS } \\
\text { INDRA } \\
\text { IEVA } \\
\text { BEĀTE } \\
\text { JURIJS } \\
\text { NEDAS } \\
\text { AISTE் } \\
\text { MARIJA }\end{array}$ \\
\hline
\end{tabular}

2. attēls. Mācību līdzeklī iekḷautais personvārdu uzdevums (21).

Starp tiem ir gan citvalodu cilmes vārdi, kurus abās baltu valodās lieto mazliet atšksirīgi noformētus (Regīna/Regina, Beāte/Beata, Kristīne/Kristina, Ériks/Erikas, Jānis/Jonas), gan pašcilmes vārdi, piem., Lina, Ugné; daži no tiem, parasti meiteņu, var būt abu valodu vārdi, jo ir ar galotni -a-Rasa, Ieva, Laima, Indra, Inga, Vilma, Laura, Marija, Irma - turklāt tajos nav diakritisko zìmju, kuras ḷautu diferencēt valodas (noskaidrot vārdu cilmi var latviešu un lietuviešu personvārdu vārdnīcās Siliņš 1990 un Kuzavinis, Savukynas 1994). Šì uzdevuma mērksis ir ne vien iepazīstināt ar citas tautas personvārdiem, bet 
arī pievērst uzman̄ibu uzsvara atšķirībām, piem., Rasa, Marija, kuri šķiet tik līdzīgi, lietuviešu valodā tiek uzsvērta pēdējā zilbe.

\section{Rotaḷnodarbības un citas darbības valodas mācīšanā}

Dažādas neatbilstības un variēšana var apgrūtināt valodas apguvi, kā arī radīt nesaprašanos starp latvieti un lietuvieti, jo pasaules izziņa notiek ar savas valodas starpniecību, resp., palīdz jau zināmais. Ar laiku tieksme salīdzināt kḷūst arvien stiprāka, tāpēc valodas mācǐšanai agrīnā vecumā ir savas priekšrocības: bērns rotậādamies viegli apgūst jaunas zināšanas. Pirmsskolas vecumā, apgūstot valodu, īpaši piemērota ir rotaļnodarbība - „[m]ācību organizācijas forma darbā ar pirmsskolas un jaunākā skolas vecuma bērniem, lai atbilstīgi viņu vecuma īpatnībām veicinātu brīvu, nepiespiestu fizisko, kognitīvo, sociāli emocionālo un radošo attīstību. Valodas mācību procesā rotaļnodarbībā kā metodiskie paņēmieni tiek izmantoti rotaļas un spēles” (Skujiņa et al. 2011, 74). Mācību līdzeklī ieklạautas dziesmas, rotaḷas u. tml. nodarbības - galvenokārt tādas, kam ir analogi dzimtajā kultūrā. Tādējādi bērns tās vieglāk apgūs svešvalodā. Piem., tiek piedāvāta muzikālā rotalıa - lietuviešu tautasdziesma Dvi vištytès baltos (tā gan Laimoņa Kamaras atdzejojumā latviešu valodā kḷuvusi par Divi cāḷi balti (30-31), kaut gan atbilstoši avotvalodai būtu Divas vistinas baltas).

Padomāts arī par nepieciešamību sniegt bērniem pamatinformāciju par kaimiņu valsti - iepazīstināt ar valsts atribūtiku, tās valūtu (vienlaicīgi bērns mācās skaitīt abās valodās) (darbības vārds skaitīt ḷoti līdzīgs lietuviešu valodas vārdam skaityti, kas nozīmē 'lasīt'; plašāk par to sk. sadaḷā 2.1.) u. tml. Projekta otrajā grāmatiņā (Krūminienè, Motviekaitė 2010b) ir dažādu praktisko darbu - izkrāsošanai, izgriešanai paredzētu attēlu, rokdarbu u. c. - paraugi, ko pedagogi var izmantot, mācot valodu. Attēlu izmantošana valodas mācīšanā ir vēl viens no veidiem, kas rosina radošumu. ,,...] agrīnajā vecumā nepieciešams daudz vairāk gādāt ne tikai par bērna fizisko un emocionālo, bet arī par intelektuālo attīstību. Bērni ir spējīgi uzņemt daudz vairāk informācijas, nekā mēs tiem sniedzam. Turklāt agrīnā vecumā uzņemtā informācija dzīves laikā nezūd. Tādēl atteiksimies no mītiem par bilingvisma kaitīgo ietekmi un mācīsim bērniem valodas - jo ātrāk, jo labāk, jo vairāk, jo labāk”" (Druviete 2000).

Svarīga nozīme, mācoties otro baltu valodu, ir arī citiem faktoriem, piem., iespējai šajā valodā sazināties. Pirmsskolas vecuma bērniem vispievilcīgākā varētu šķist sazināšanās un satikšanās ar vienaudžiem, kuru dzimtā valoda ir tā, ko mācās viņi. Valodas apguvi sekmē arī teritoriju, kur runā mācību valodā, apmeklēšana, kur iespējams dzirdēt to dabiskā vidē. Šādas priekšrocības dod projekts, jo sagatavošanās valodas apguvei saistīta arī ar piedalīšanos kopīgās nodarbībās, apmaiņa ar delegācijām un kopīgu pasākumu, ieskaitot dažādu 
kopīgu nometņu partnervalstīs, rīkošana. Žeimeles un Rundāles bērnudārzu sadarbība apliecināja, ka projektā labprāt iesaistās arī vecāki, bet ir svarīgi ḷaut bērniem radoši izpausties, piedalīties vietējās kopienas dzīvē. Visas projektā paredzētās darbības rosinās vēlěšanos mācīties otro baltu valodu un veiksmīgi to $\overline{1} s t e n \mathrm{t}^{14}$.

\section{Secinājumi}

Viens no projektā iesaistīto Lietuvas un Latvijas bērnudārzu sadarbības mērķiem - apgūt otro baltu valodu. Lai šo mērķi sasniegtu, lietuviešu audzinātājas sagatavoja bērniem piemērotu mācību līdzekli, kas tika pārtulkots latviešu valodā, un sarīkoja semināru bērnudārza personālam par agrīno valodas mācīšanu, orientējoties uz pierobežas specifiku.

Analizējot ikdienas sazinaā aktuālo un valodas apguves sākumposmā apgūstamo pamatleksiku, konstatēts, ka semantiskās atšķirības pastāv starp dažādu latviešu un lietuviešu valodas vārdšķiru vārdiem, taču īpaši daudz - starp lietvārdiem un īpašības vārdiem. Pētījums apliecināja, ka svarīgi ir izvēlēties pirmsskolas vecuma bērnam vieglāk iegaumējamu vārdu cilvēka, sadzīves priekšmeta, vides objekta $u$. tml. nosaukšanai, ja svešvalodā lieto vairākus sinonīmus, kā arī nepārspīlēt, darinot un lietojot deminutīvus. Deminutīvu dažādība un bagātība ir raksturīga abām baltu valodām, bet, mācot otro valodu, sākumā pilnīgi pietiktu ar dažām leksēmām (vēlams būtu tās konsekventi atkārtot) katrā no valodām, turklāt nepieciešams veidot vienotu leksiski semantisko sistēmu. Iepazīstinot ar citas tautas personvārdiem, uzmanība jāpievērš to formu atškirīīām.

Agrīnā otrās baltu valodas mācīšana dos pozitīvus rezultātus, ja notiks kompleksi - iesaistot vecākus un sabiedrību, rīkojot kopīgas nometnes u. tml. Viens no piemērotākajiem veidiem, kā rosināt pirmsskolas vecuma bērnu radošumu, ir rotaḷnodarbības, kuru piemērus var atrast arī analizētajos avotos. Lai attīstītu komunikatīvās spējas, īpaši lietderīga ir Lietuvas un Latvijas bērnudārzu audzinātāju un tā paša vecuma bērnu sazināšanās, apmaiņas braucieni, kopīgas abu tautību bērnu nometnes un mācīšanās. Pedagogiem nepieciešami arī piemēroti mācību līdzekḷi, no kuriem smelties ierosmes otrās baltu valodas mācīšanai, taču gan projekta ietvaros sagatavotais mācību līdzeklis, gan citi mācību līdzekḷ̣i jāizmanto radoši, kritiski jāvērtē tajos iekḷautais materiāls.

\footnotetext{
${ }^{14}$ Sazinoties ar projekta koordinatori no Žeimeles Laimu Karpavičūti (Laima Karpavičiūtè), izdevās uzzināt, ka, pateicoties projektam, viņiem tagad ir radies daudz vairāk draugu Latvijā un ir iespējas turpināt valodas mācǐšnu gan sava bērnudārza bērniem, gan izplatīt savu pieredzi citām mācību iestādēm. To šì pirmsskolas mācību iestāde dara, izmantodama darbā arī rakstā aplūkotos mācību līdzekḷ̣us.
} 


\section{Avoti un literatūra}

1. Balkevičs, Jons et al. 1995. Lietuviešu-latviešu vārdnīca. Rīga: Zinātne.

2. Butkienè, Violeta. 1998. Latviu kalbos leksikos minimumas. Kaunas: Aesti.

3. Butkienè, Violeta, Vaisvalavičienè, Kristina (sast.). B. g. Baltu kalbu pradžiamokslis. Baltu valodu ābece. Kaunas: MMVI.

4. Butkus, Alvydas. 1995. Latviai. Kaunas: Aesti.

5. Butkus, Alvydas (red.). 2003. Latvių-lietuvių kalbų žodynas. Kaunas: Aesti.

6. Butkus, Alvydas. 1990. Mūsų broliai latviai. Vilnius: Mokslas.

7. Ceplītis, Laimdots, Stengrevica, Melita (red.). 1972-1996. Latviešu literārās valodas vārdnīca. Rīga: Zinātne.

8. Dabašinskienè, Ineta, Garuckaite, Raminta. 2009. Ankstyvasis užsienio kalbos mokymas - neatsakyti klausimai. Kalbos kultūra 82, 294-307.

9. Druviete, Ina. 2000. Bilingvālā izglītība - bērnu spējām un intelektam. Skolotājs. 5, 65-67.

10. Koskienè, Nijolè. Kai tarp dvieju vaiku darželiu - latviu ir lietuviu - vos 12 kilometrų. Komentaras Svetima kalba - lyg žaidimas. [prieiga per internetą www. ikimokyklinis.lt 201211 27]

11. Krūminienè, Liuda, Motviekaitè, Elita. 2010a. Pažink save ir savo draugus. Pratybų knygelè. Iepazīsti sevi un savus draugus. Uzdevumu grāmatiņa. Šiauliai: S. Tumèno leidykla „Šiaurès Lietuva”.

12. Krūminienè, Liuda, Motviekaitè, Elita. 2010b. Pažink save ir savo draugus. Pratybų knygelès priedai. Iepazīsti sevi un savus draugus. Uzdevumu grāmatinas pielikumi. Šiauliai: S. Tumèno leidykla „Šiaurès Lietuva”.

13. Kuzavinis, Kazys, Savukynas, Bronys. 1994. Lietuviu vardų kilmès žodynas. Vilnius: Mokslo ir enciklopedijų leidykla.

14. Kvašìte, Regīna. 2011. Lietuviešu un latviešu personvārdu atveides gramatiskie aspekti. Valoda - 2011. Valoda dažādu kultūru kontekstā. Zinātnisko rakstu krājums XXI. Daugavpils: Daugavpils Universitātes Akadēmiskais apgāds „Saule”, 124-134.

15. Kvashite, Regina. 2011. Obuchenie nerodnomu jazyku: iz opyta litovskolatyshskogo prigranich'ja. Materialy mezhdunarodnoj nauchnoj konferencii Dvujazychnoe obrazovanie: teorija i praktika. (26-28 aprelja 2011 g. Hel'sinki, Finljandija). Kopoteva, V. M., Protasova, E. Ju. (red.). Hel'sinki: Hel'sinkskij universitet; Sankt-Peterburg: Zlatoust, 118-119.

16. Lyberis, Antanas. 2002. Sinonimu žodynas. Antrasis pataisytas leidimas. Vilnius: Lietuvių kalbos institutas.

17. Macienè, Jurgita. 2005. Deminutyvų stilistika. Šiauliai: Vš̃ Šiaulių universiteto leidykla.

18. Macienè, Jurgita. 2002. Lietuvių vardų deminutyvai: daryba ir vartojimas. Vārds un tā pètī̌sanas aspekti 6. Liepāja: LPA, 132-141.

19. Markus, Dace, Zīriņa, Tija. 2016. Bērnu komunikācijas prasme. Bērnu valoda Latvijā 21. gadsimtā II. Rīga: RaKa, 199-210.

20. Ramonienè, Meilutè et al. 2012. Lingvodidaktikos terminu žodynas. Vilnius: Vilniaus universitetas. 
21. Rauhvargers, Eižens (red.). 2002. Latviešu valodas sinonīmu vārdnīca. 3. papild. un pārstr. izd. Rīga: Avots.

22. Rūkse-Draviņa, Velta. 2017. 'Mama' and 'Papa' in child language. Darbu izlase. Rīga: Latviešu valodas institūts, 68-77.

23. Siliņš, Klāvs. 1990. Latviešu personvārdu vārdnīca. Rīga: Zinātne.

24. Skujiņa, Velentīna et al. 2007. Valodniecības pamatterminu skaidrojošā vārdnīca. Rīga: LU Latviešu valodas institūts.

25. Skujiņa, Valentīna et al. 2011. Lingvodidaktikas terminu skaidrojošā vārdnīca. Rīga: Latviešu valodas aǵgentūra, Latviešu valodas institūts.

26. Skujiņa, Valentīna et al. 2000. Pedagoǵijas terminu skaidrojošā vārdnīca. Rīga: Zvaigzne ABC.

27. Šalme, Arvils. 2011. Latviešu valodas kā svešvalodas apguves pamatjautājumi. Rīga: Latviešu valodas ag̊entūra.

28. Trumpa, Anta. 2010. Adjektīou semantiskā diferenciācija latviešu un lietuviešu valodā. Rīga: LU Latviešu valodas institūts.

29. Vaisvalavičienè, Kristina (sast.). B. g. Baltu kalbu pradžiamokslis. Baltu valodu äbece. Kaunas: MMVI.

30. Vanagas, Aleksandras. 1996. Lietuvos miesty vardai. Vilnius: Mokslo ir enciklopedijų leidykla.

31. Vulāne, Anna. 2007. Deminutīvs bērna emocionālajā pieredzē. Vecuma grupu valodas ìpatnības Latvijā: lingvistiskais, sociālais un kultūras aspekts. Bērnība. Rīga: SIA Izglītības soḷi, 79-92.

\section{Summary}

The teaching neighbouring, i.e. Lithuanian and Latvian, languages as foreign languages on the territories of Latvia and Lithuania is the topic of this paper. The need to know (learn) the Latvian language for Lithuanians and the Lithuanian language for Latvians is recognised, especially at the non-official level; however, a possibility to implement it is limited by various reasons. This issue is dealt with when there is a need to underline existing or potentially possible collaboration of both countries. Usually, the conclusion is unambiguous: the present situation is unsatisfactory, but in order to improve it neither means nor possibilities are allocated. Worked out and being implemented projects of various regional institutions can help improve the situation. One of the ideas has been substantiated as a project „Creating of Cooperation System between Preschool Educational Institution on Lithuania-Latvia Border". It is important to discuss possibilities for teaching a foreign language - the second Baltic language - to pre-school age children at the crossborder region of Lithuania and Latvia. The crossborder collaboration project carried out by pre-school education institutions in Žeimelis (Lithuania) and Rundāle (Latvia) is dealt with; also, teaching aid materials prepared and published in the framework of this project are introduced. The research has been conducted by applying the descriptive and comparative methods.

Broad dissemination and practical application of Baltic languages teaching can be facilitated by the coursebooks prepared and published in the framework of the project. 
Thanks to educators of a particular Lithuanian kindergarten, educators of kindergartens of the crossborder region will be able to use an original bilingual coursebook „Pažink save ir savo draugus. Iepazīsti sevi un savus draugus” [Get to Know Yourself and Your Friends] and its supplement in teaching Lithuanian and Latvian. This publication may be successfully used in schools of the crossborder region (and not only) where the Lithuanian and Latvian languages are being taught too.

Cognation of the Lithuanian and Latvian languages obliges us to pay special attention to the selection of linguistic material. It is related both to pre-school age children (in the present project) and any age learners of a foreign language. Here, both semantic differences of particular words and selection of the most suitable word out of several synonyms etc. are of high importance.

Various activities are dedicated to promotion of collaboration of pre-school education institutions in the crossborder regions of Latvia and Lithuania. The teaching of the second Baltic language is highly important when aiming at children's development. Moreover, the socialising of kindergarten educators and pupils, their exchange visits and joint learning are helpful in development of communicative skills and foreign language acquisition. 